\title{
Effects of Amide-Protected and Lipid-Encapsulated Conjugated Linoleic Acid (CLA) Supplements on Milk Fat Synthesis*
}

\author{
J. W. Perfield, II, ${ }^{1}$ A. L. Lock, ${ }^{1}$ A. M. Pfeiffer, ${ }^{2}$ and D. E. Bauman ${ }^{1}$ \\ ${ }^{1}$ Department of Animal Science, \\ Cornell University, Ithaca, NY 14853 \\ 2BASF Aktiengesellschaft, Nutrition Research Station, \\ Offenbach, Germany
}

\section{ABSTRACT}

The trans-10, cis-12 isomer of conjugated linoleic acid (CLA) is a potent inhibitor of milk fat synthesis; its ability to reduce milk fat output in a controlled manner as a feed supplement, has potential management applications in the dairy industry. The effectiveness of dietary supplements of trans-10, cis-12 CLA is related to the extent to which their metabolism by rumen bacteria is minimized. A number of processes have been used to manufacture "rumen-protected" feed supplements, and their efficacy can be described by the extent of protection from rumen bacteria as well as postruminal bioavailability. The objective of this study was to investigate the effects of 2 rumen-protected CLA supplements on milk fat synthesis. Using the same initial batch of CLA, supplements were manufactured by the formation of fatty acyl amide bonds or by lipid encapsulation. Three rumen fistulated Holstein cows were randomly assigned in a $3 \times 3$ Latin square experiment. Treatments were 1) no supplement (control), 2) amideprotected CLA supplement, and 3) lipid-encapsulated CLA supplement. Supplements were fed to provide 10 $\mathrm{g} / \mathrm{d}$ of the trans-10, cis-12 CLA isomer. Over the 7-d treatment period, 21 and $22 \%$ reductions in milk fat yield were observed for the amide-protected and lipidencapsulated supplements, respectively. Transfer of trans-10, cis-12 CLA into milk fat was also similar for the amide-protected (7.1\%) and lipid-encapsulated (7.9\%) supplements. Overall, the amide-protected and lipid-encapsulated CLA supplements were equally effective at reducing milk fat synthesis and had no effect on milk yield or dry matter intake.

(Key words: conjugated linoleic acid, milk fat depression, rumen-protected supplement, cow)

Received January 27, 2004.

Accepted March 9, 2004.

Corresponding author: D. E. Bauman; e-mail: deb6@cornell.edu.

*Supported in part by BASF AG (Ludwigshafen, Germany), Balchem Encapsulates (New Hampton, NY), and Cornell Agricultural Experiment Station.
Abbreviation key: AP-CLA = amide-protected CLA supplement, CLA = conjugated linoleic acid, LE-CLA = lipid-encapsulated CLA supplement.

\section{INTRODUCTION}

Conjugated linoleic acid (CLA) is a collective term for different positional and geometric configurations of octadecadienoic acid containing a pair of double bonds in a conjugated configuration. Supplementation with various mixtures of CLA isomers has been shown to reduce milk fat content in lactating cows (Loor and Herbein, 1998; Chouinard et al., 1999a, 1999b; Mackle et al., 2003). Comparisons of relatively pure CLA isomers infused into the abomasum identified trans-10, cis-12 CLA to be a potent inhibitor of milk fat synthesis, while cis-9, trans-11 CLA (Baumgard et al., 2000, 2002; Loor and Herbein, 2003) as well as trans-8, cis-10 CLA and cis-11, trans-13 CLA (Perfield et al., 2004) had no effect on milk fat synthesis. Subsequent studies abomasally infused various doses of trans-10, cis-12 CLA and demonstrated a curvilinear relationship between the percent reduction in milk fat yield and both the dose of trans-10, cis-12 CLA and the milk fat content of trans10, cis-12 CLA (Baumgard et al., 2001; Peterson et al., 2002).

A technology to reduce milk fat output in a controlled manner has potential application as a management tool (Bauman et al., 2001). However, the effectiveness of dietary supplements of trans-10, cis-12 CLA will be related to the extent that their metabolism by rumen bacteria is avoided. A number of processes have been used to produce "rumen-protected" supplements, and their efficacy is characterized by the extent of their protection from rumen bacteria and postruminal bioavailability (Wu and Papas, 1997). These include formation of calcium salts, fatty acyl amides, formaldehydeprotein matrix protection, and lipid encapsulation. To date, the majority of research conducted with rumenprotected CLA has used supplements consisting of calcium salts of FFA (Giesy et al., 2002; Perfield et al., 2002; Bernal-Santos et al., 2003). Data from these stud- 
Table 1. Ingredient and chemical composition of diet.

\begin{tabular}{lc}
\hline Composition $^{1}$ & Concentration \\
\hline Ingredient, \% of DM & \\
Alfalfa hay & 52.6 \\
Cracked corn & 29.8 \\
Soybean meal & 4.0 \\
Expeller soybean meal & 4.0 \\
Whole cottonseed & 7.0 \\
Dicalcium phosphate & 0.3 \\
Salt & 0.4 \\
Vitamin and mineral mix $^{2}$ & 2.0 \\
Chemical analysis, \% of DM & \\
CP & 16.0 \\
Crude fat & 4.6 \\
NDF & 45.2 \\
ADF & 31.2 \\
NE & 1.6 \\
\hline
\end{tabular}

${ }^{1}$ Ingredient and chemical composition values do not include the rumen-protected conjugated linoleic acid supplements.

${ }^{2}$ Contained $17.94 \% \mathrm{Ca}, 1.53 \% \mathrm{Zn}, 0.40 \% \mathrm{Mn}, 0.07 \% \mathrm{Cu}, 0.01 \% \mathrm{P}$, $0.006 \%$ Co, $765 \mathrm{IU} / \mathrm{g}$ of vitamin A, $124 \mathrm{IU} / \mathrm{g}$ of vitamin D, and 4.1 IU/g of vitamin $\mathrm{E}$.

ies provide incentive to continue evaluating the use of controlled milk fat depression as a management tool. However, CLA supplements formulated with other methods of rumen protection have not been adequately examined. The objective of the present study was to investigate 2 supplements; an FFA form of CLA that was bound by amide bonds and a lipid-encapsulated supplement that contained methyl esters of CLA.

\section{MATERIALS AND METHODS}

The Cornell University Institutional Animal Care and Use Committee approved all procedures involving animals. Three multiparous lactating Holstein cows fitted with rumen fistulas (78 \pm 13 DIM; mean \pm SD) were randomly assigned in a $3 \times 3$ Latin square experiment. Cows were housed in tie stalls at the Cornell University Large Animal Teaching and Research Unit and fed a TMR formulated to meet or exceed nutrient requirements (NRC, 2001) using the Cornell Net Carbohydrate and Protein System (Fox et al., 1992). Chopped alfalfa was the major forage component with cracked corn as the major concentrate (Table 1). Cows were fed ad libitum with equal portions of feed offered at 0700 and $1900 \mathrm{~h}$ daily. Water was available at all times.

Cows were milked at 0700 and $1900 \mathrm{~h}$ daily. Yield was determined and samples were taken from each milking. One aliquot was stored with preservative (bronopol tablet; D\&F Control System, San Ramon, CA) at $4^{\circ} \mathrm{C}$ until analyzed for fat and true protein using infrared analysis and calibration as described by BernalSantos et al. (2003). A second aliquot was taken for analysis of fatty acid composition and stored without preservative at $-20^{\circ} \mathrm{C}$.
Table 2. Fatty acid profile of rumen-protected supplements of conjugated linoleic acid (CLA). ${ }^{1}$

\begin{tabular}{lccc}
\hline Fatty acid, $\%$ & Source CLA & AP-CLA & LE-CLA \\
\hline 16:0 & 5.1 & 5.9 & 10.6 \\
18:0 & 4.3 & 4.8 & 55.4 \\
18:1 cis-9 & 25.4 & 27.2 & 8.2 \\
18:2 cis-9, cis-12 & 0.4 & 0.3 & 1.7 \\
Conjugated linoleic acid & & & \\
18:2 cis-9, trans-11 & 29.7 & 24.7 & 9.3 \\
Unidentified & ND & 3.4 & ND \\
18:2 trans-10, cis-12 & 29.6 & 21.1 & 9.2 \\
Other & 5.5 & 12.7 & 5.6 \\
\hline
\end{tabular}

${ }^{1}$ Supplements were amide-protected CLA (AP-CLA) and lipid-encapsulated CLA (LE-CLA).

${ }^{2}$ Unidentified fatty acid whose retention time was located between cis-9, trans-11 CLA and trans-10, cis-12 CLA (see text for discussion).

${ }^{3} \mathrm{ND}=$ Not detected.

The CLA used for the manufacture of the rumenprotected supplements originated from the same batch and was supplied by BASF AG (Ludwigshafen, Germany). Treatments were: 1) no supplement (control), 2) amide-protected CLA (AP-CLA; 54 g/d) (Akzo Nobel Chemicals, Inc., Dobbs Ferry, NY), and 3) lipid-encapsulated CLA (LE-CLA; 138 g/d) (Balchem Encapsulates, New Hampton, NY). The fatty acid composition of the supplements is provided in Table 2 , and the daily amount was designed to provide $10 \mathrm{~g}$ of trans-10, cis12 CLA. To ensure exact intakes, rumen-protected supplements were placed directly into the rumen through the fistula and mixed into the rumen contents once per day after the evening milking. The AP-CLA supplement, which was a solid at room temperature, was heated and a predetermined quantity placed on a small amount of feed, and then allowed to cool before being placed in the rumen. The LE-CLA supplement was a powder at room temperature and was administered as such. Treatment periods were $7 \mathrm{~d}$ in duration, and each treatment period was followed by a $7 \mathrm{~d}$ washout period.

\section{Fatty Acid Analysis}

Total fat content of the AP-CLA supplement was determined using acid hydrolysis (AOAC 2000: method 945.02), and ether extraction (FOSS Tecator Soxtec System, Foss North America, Eden Prairie, MN, Application Subnote AN 3414) was used to determine the fat content of the LE-CLA supplement (Dairy One Cooperative Inc., Ithaca, NY). Milk fat was extracted using the method of Hara and Radin (1978). Fatty acid methyl esters from the lipid extracted from the LE-CLA supplement and milk fat extracts were prepared by base-catalyzed transmethylation according to Christie (1982) with modifications by Chouinard et al. (1999a). Fatty acid methyl esters from the lipid extracted from the AP- 
CLA supplement were prepared using $1 \%$ methanolic sulfuric acid as described by Christie (1989).

Fatty acid methyl esters were quantified using a gas chromatograph (GCD system HP 6890+; Hewlett Packard, Avondale, PA) equipped with a CP-SIL 88 fused silica capillary column $(100 \mathrm{~m} \times 0.25 \mathrm{~mm}$ (i.d. $)$ with 0.2 $\mu \mathrm{m}$ film thickness; Varian, Inc., Walnut Creek, CA). Gas chromatograph conditions were as described by Perfield et al. (2002). Fatty acid peaks were identified using pure methyl ester standards (Nu-Chek Prep, Elysian, MN). Additional standards for CLA isomers were obtained from Natural ASA (Hovdebygda, Norway). A butter oil reference standard (CRM 164; Commission of the European Community Bureau of References, Brussels, Belgium) was used to determine recoveries and correction factors for individual fatty acids.

\section{Statistical Analysis}

Data were statistically analyzed as a $3 \times 3$ Latin square design using the PROC MIXED procedure of SAS (2001). The model is: $\mathrm{Y}_{\mathrm{ijk}}=\mu+\mathrm{T}_{\mathrm{i}}+\mathrm{P}_{\mathrm{j}}+\mathrm{C}_{\mathrm{k}}+$ $E_{i j k}$, where $Y_{i j k}$ is observation, $\mu$ is overall mean, $T_{i}$ is treatment ( $i=1,2$, and 3$), P_{j}$ is period $(j=1,2$, and 3 ), $\mathrm{C}_{\mathrm{k}}$ is cow $(\mathrm{k}=1,2$, and 3$)$, and $\mathrm{E}_{\mathrm{ijk}}$ is residual error.

\section{RESULTS}

The AP-CLA and LE-CLA supplements are novel products, and analysis of total fat as well as fatty acid composition for each posed unique challenges. Determining total fat for the AP-CLA supplement required acidic conditions that were severe enough to break the amide bonds (Christie, 1989). We found that this required acid hydrolysis of the amide-protected CLA, and results indicated that the supplement had a lipid content of $87 \pm 1.5 \%$ (mean $\pm \mathrm{SD} ; \mathrm{n}=3$ ). The extracted lipid was in the FFA form, and this was considered in selecting the methylation method.

The LE-CLA supplement was manufactured by binding methyl esters of CLA to a silica matrix, and then coating this complex with hydrogenated soybean oil, which contained fatty acids in the triglyceride form. To extract total fat, an ether soxhlet extraction was used; the refluxing involved in this procedure was important for extracting the stearic acid which otherwise adhered to the silica once cooling began. Extraction was performed in triplicate, and the fat content averaged $72 \pm$ $0 \%$ for the LE-CLA supplement. This supplement was manufactured from CLA methyl esters so that only the hydrogenated soybean oil component of the supplement required methylation and this was done using a basecatalyzed transmethylation as described previously.

Fatty acid analysis of the rumen-protected CLA supplements is presented in Table 2. Unique to the AP-CLA

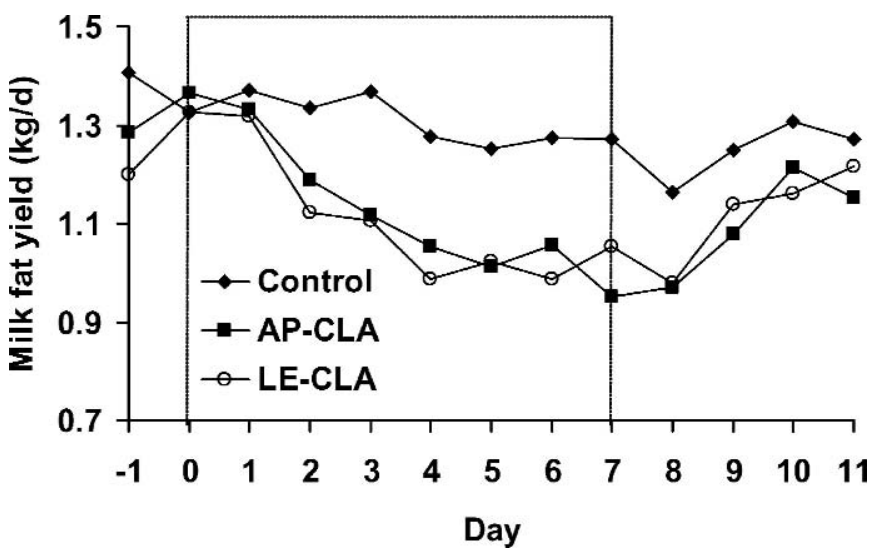

Figure 1. Temporal pattern of milk fat yield during supplementation of rumen-protected CLA supplements [amide-protected CLA(APCLA); lipid-encapsulated CLA (LE-CLA)]. Animals received supplements for $7 \mathrm{~d}$ (dotted lines). Values represent means from 3 cows; $\mathrm{SEM}=0.079 \mathrm{~kg} / \mathrm{d}$.

supplement was a sizable peak that eluted between the peaks for the cis-9, trans-11 CLA and trans-10, cis-12 CLA isomers. The lower proportion of trans-10, cis-12 CLA, suggests that this unique fatty acid is cis-11, trans-13 CLA produced by a thermal [1,5] sigmatropic rearrangement, which is common under the temperature conditions required for the manufacture of the APCLA supplement (Sæbø, 2003). Although an acid methylation was used, we are confident that the observed rearrangement was due to manufacturing conditions as this unique peak was not present when we conducted a test where the LE-CLA supplement and pure trans10, cis-12 CLA were methylated under the same conditions (data not shown). Most likely, trans-8, cis-10 CLA was also formed through the same transformation from the cis-9, trans-11 CLA isomer, but was not identified due to coelution with the cis-9, trans-11 CLA isomer under the analytical conditions we used. The addition of hydrogenated soybean oil to the LE-CLA product resulted in a stearic acid content of this supplement that was about 10 times greater than that of the APCLA supplement.

The AP-CLA and LE-CLA supplements were supplied in quantities so that each provided $10.0 \mathrm{~g} / \mathrm{d}$ of trans-10, cis-12 CLA. The temporal pattern for milk fat yield demonstrated a progressive reduction for cows receiving the CLA supplements that had reached nadir by $\mathrm{d} 4$, while no change in milk fat yield was observed for the control (Figure 1). When supplements were terminated, the temporal pattern indicated a return to previous milk fat yield for the AP-CLA and LE-CLA treatment groups. Overall, the 2 CLA supplements caused similar reductions in milk fat content and milk 
Table 3. Performance of lactating dairy cows receiving rumen-protected supplements of conjugated linoleic acid (CLA)., ${ }^{1,2}$

\begin{tabular}{|c|c|c|c|c|c|}
\hline \multirow[b]{2}{*}{ Variable } & \multicolumn{3}{|c|}{ Treatment } & \multirow[b]{2}{*}{ SEM } & \multirow[b]{2}{*}{$P^{3}$} \\
\hline & Control & AP-CLA & LE-CLA & & \\
\hline DMI, kg/d & 30.6 & 31.6 & 30.4 & 0.9 & 0.50 \\
\hline Milk, kg/d & 40.5 & 42.6 & 42.7 & 3.5 & 0.32 \\
\hline $\begin{array}{l}\text { Milk fat } \\
\% \\
\mathrm{~kg} / \mathrm{d}\end{array}$ & $\begin{array}{l}3.23^{\mathrm{a}} \\
1.272^{\mathrm{a}}\end{array}$ & $\begin{array}{l}2.37^{\mathrm{b}} \\
1.004^{\mathrm{b}}\end{array}$ & $\begin{array}{l}2.34^{\mathrm{b}} \\
0.992^{\mathrm{b}}\end{array}$ & $\begin{array}{l}0.15 \\
0.079\end{array}$ & $\begin{array}{l}<0.001 \\
<0.001\end{array}$ \\
\hline Milk protein & & & & & \\
\hline $\begin{array}{l}\% \\
\mathrm{~kg} / \mathrm{d}\end{array}$ & $\begin{array}{l}2.55 \\
1.001^{b}\end{array}$ & $\begin{array}{l}2.51 \\
1.063^{\mathrm{a}}\end{array}$ & $\begin{array}{l}2.58 \\
1.086^{\mathrm{a}}\end{array}$ & $\begin{array}{l}0.12 \\
0.023\end{array}$ & $\begin{array}{l}0.07 \\
0.02\end{array}$ \\
\hline
\end{tabular}

${ }^{\mathrm{a}, \mathrm{b}}$ Means within a row with different superscripts differ.

${ }^{1}$ Supplements were amide-protected CLA (AP-CLA) and lipid-encapsulated CLA (LE-CLA).

${ }^{2}$ Values represent an average of day 6 and 7 of supplementation.

${ }^{3}$ Statistical probability of treatment effects.

fat yield (Table 3). In contrast to milk fat, CLA supplements had no effect on DMI or milk yield (Table 3). A trend for increased milk protein content $(P<0.07)$, as well as a small but statistically significant increase in protein yield was observed when cows received the CLA supplements.

The observed reduction in milk fat yield was due to decreases in fatty acids originating from both de novo fatty acid synthesis and uptake of preformed fatty acids from circulation (Table 4). However, there was a greater reduction of de novo synthesized fatty acids resulting in a relative increase in the proportion of preformed fatty acids in milk fat. The milk fat content of both CLA isomers present in the supplements was increased, and the increases in cis-9, trans-11 CLA, and trans-10, cis12 CLA were similar for the AP-CLA and LE-CLA supplements (Table 4).

\section{DISCUSSION}

Several methods have been used to reduce the extent to which lipid supplements are metabolized by rumen bacteria. These include the formation of calcium salts, linkage by amide bonds, formaldehyde treatment, and lipid encapsulation. The form of fatty acid required for the production of these supplements varies, and becomes an important consideration due to the variation in manufacturing processes and costs associated with the production of different lipid forms (Sæbø, 2003). For example, the production of calcium salts, or a simple amide-protected supplement, requires that the starting material be FFA. However, other amide-protected supplements have been manufactured from oils (Jenkins, 1995, 1998), and esters or other forms can be used for formaldehyde protection or lipid-encapsulation. Calcium salts of fatty acids have been commercially used as a dietary lipid supplement for dairy cows, and they have also been experimentally used to provide rumenprotected supplements of CLA (Giesy et al., 2002; Perfield et al., 2002; Bernal-Santos et al. 2003). Other methods of rumen protection for CLA have not been investigated, with the exception of a short-term study with formaldehyde-protected CLA in lactating goats (Gulati et al., 2000). The present study examined the use of amide protection and lipid encapsulation as methods to supply CLA. The use of amide bonds as a method to provide lipid supplements to ruminants has been discussed by Jenkins (1998). Putnam et al. (2003) has reviewed lipid encapsulation, and this method has been commercially used to provide choline supplements to dairy cows.

In the present study, the amide-protected supplement provided CLA as free fatty acids, whereas the lipid-encapsulated supplement provided CLA as methyl esters. Recent work has shown that the FFA and methyl ester forms of trans-10, cis-12 CLA are equally effective in reducing milk fat synthesis when supplied by abomasal infusion (de Veth et al., 2004). We observed a gradual reduction in milk fat yield over the first few days of treatment and a return to control values when the supplement was terminated (Figure 1), and this is similar to changes observed when trans-10, cis-12 CLA was abomasally infused (Baumgard et al., 2000, 2001; Mackle et al., 2003) or provided intravenously (Viswanadha et al., 2003). The AP-CLA and LE-CLA supplements resulted in decreased secretion of milk fatty acids of all chain lengths, but the reduction was relatively greater for milk fatty acids containing $\leq 16$ carbons (Table 4). These reductions are similar to those observed when milk fat depression is caused by abomasal infusion of trans-10, cis-12 CLA (Baumgard et al., 2001; Loor and Herbein, 2003; Mackle et al., 2003) or by feeding of calcium salts of CLA (Giesy et al., 2002; Perfield et al., 2002; Bernal-Santos et al., 2003). A lack of an effect on the ratio of fatty acid pairs reflecting $\Delta^{9}$-desaturase activity has also been observed when low doses of trans-10, cis-12 CLA were abomasally infused (Peterson et al., 2002) or when calcium salts of CLA were fed (Perfield et al., 2002; Bernal-Santos et al., 2003). In contrast, higher doses of trans-10, cis-12 CLA have been shown to inhibit $\Delta^{9}$-desaturase causing a decrease in the desaturase index (Baumgard et al., 2001; Loor and Herbein, 2003; Mackle et al., 2003).

The AP-CLA and LE-CLA supplements caused similar reductions in milk fat content and milk fat yield, with no effects on DMI or milk yield (Table 3). Specific effects of CLA on milk fat are consistent with results from a longer term study using rumen-protected CLA in the form of calcium salts (Perfield et al., 2002) as well as short-term studies involving abomasal infusions 
Table 4. Composition of milk fat from cows receiving of rumen-protected supplements of conjugated linoleic acid (CLA). ${ }^{1,2}$

\begin{tabular}{|c|c|c|c|c|c|}
\hline \multirow[b]{2}{*}{ Fatty acid, \% } & \multicolumn{3}{|c|}{ Treatment } & \multirow[b]{2}{*}{ SEM } & \multirow[b]{2}{*}{$P^{3}$} \\
\hline & Control & AP-CLA & LE-CLA & & \\
\hline 4:0 & $4.24^{\mathrm{a}}$ & $3.96^{\mathrm{b}}$ & $3.96^{\mathrm{b}}$ & 0.13 & $<0.001$ \\
\hline $6: 0$ & $2.15^{\mathrm{a}}$ & $1.65^{\mathrm{b}}$ & $1.56^{\mathrm{b}}$ & 0.08 & $<0.001$ \\
\hline $8: 0$ & $1.13^{\mathrm{a}}$ & $0.83^{\mathrm{b}}$ & $0.72^{\mathrm{c}}$ & 0.05 & $<0.001$ \\
\hline $10: 0$ & $2.30^{\mathrm{a}}$ & $1.66^{\mathrm{b}}$ & $1.45^{\mathrm{c}}$ & 0.11 & $<0.001$ \\
\hline $12: 0$ & $2.44^{\mathrm{a}}$ & $1.94^{\mathrm{b}}$ & $1.75^{\mathrm{c}}$ & 0.09 & $<0.001$ \\
\hline $14: 0$ & $9.38^{\mathrm{a}}$ & $7.99^{\mathrm{b}}$ & $7.19^{\mathrm{c}}$ & 0.30 & $<0.001$ \\
\hline $14: 1$ & $0.70^{\mathrm{a}}$ & $0.59^{b}$ & $0.58^{\mathrm{b}}$ & 0.09 & 0.01 \\
\hline $15: 0$ & 0.75 & 0.76 & 0.73 & 0.02 & 0.30 \\
\hline $16: 0$ & $25.32^{\mathrm{a}}$ & $22.83^{\mathrm{b}}$ & $22.77^{\mathrm{b}}$ & 1.74 & $<0.001$ \\
\hline $16: 1$ & 1.09 & 0.96 & 1.03 & 0.14 & 0.11 \\
\hline $17: 0$ & $0.47^{\mathrm{c}}$ & $0.51^{\mathrm{b}}$ & $0.54^{\mathrm{a}}$ & 0.01 & $<0.001$ \\
\hline $18: 0$ & $14.19^{\mathrm{b}}$ & $15.68^{\mathrm{a}}$ & $15.86^{\mathrm{a}}$ & 0.69 & $<0.01$ \\
\hline $18: 1$ trans -4 & $0.012^{\mathrm{b}}$ & $0.031^{\mathrm{a}}$ & $0.026^{\mathrm{a}}$ & 0.004 & $<0.01$ \\
\hline 18:1 trans -5 & $0.009^{b}$ & $0.022^{\mathrm{a}}$ & $0.018^{\mathrm{ab}}$ & 0.003 & 0.03 \\
\hline $18: 1$ trans $6-8$ & $0.35^{c}$ & $0.48^{\mathrm{a}}$ & $0.45^{\mathrm{b}}$ & 0.01 & $<0.001$ \\
\hline 18:1 trans -9 & $0.33^{\mathrm{c}}$ & $0.42^{\mathrm{a}}$ & $0.40^{\mathrm{b}}$ & 0.01 & $<0.001$ \\
\hline $18: 1$ trans -10 & $0.49^{\mathrm{b}}$ & $0.59^{a}$ & $0.61^{\mathrm{a}}$ & 0.01 & 0.001 \\
\hline 18:1 trans -11 & $1.75^{\mathrm{b}}$ & $2.06^{\mathrm{a}}$ & $2.12^{\mathrm{a}}$ & 0.08 & $<0.001$ \\
\hline 18:1 trans -12 & $0.62^{\mathrm{c}}$ & $0.77^{\mathrm{a}}$ & $0.73^{\mathrm{b}}$ & 0.01 & $<0.001$ \\
\hline $18: 1$ cis -9 & $25.03^{\mathrm{b}}$ & $28.31^{\mathrm{a}}$ & $28.95^{\mathrm{a}}$ & 1.28 & $<0.001$ \\
\hline $18: 2$ cis -9, cis -12 & $3.61^{\mathrm{c}}$ & $3.93^{\mathrm{b}}$ & $4.41^{\mathrm{a}}$ & 0.19 & $<0.001$ \\
\hline $18: 2$ cis -9, trans -11 & $0.57^{\mathrm{b}}$ & $0.83^{\mathrm{a}}$ & $0.80^{\mathrm{a}}$ & 0.05 & $<0.001$ \\
\hline $18: 2$ trans -10, cis -12 & $<0.01^{\mathrm{b}}$ & $0.08^{\mathrm{a}}$ & $0.09^{\mathrm{a}}$ & 0.01 & $<0.001$ \\
\hline $18: 3$ & $0.50^{\mathrm{b}}$ & $0.53^{\mathrm{a}}$ & $0.56^{\mathrm{a}}$ & 0.03 & $<0.01$ \\
\hline $20: 0$ & $0.107^{b}$ & $0.114^{\mathrm{a}}$ & $0.115^{\mathrm{a}}$ & 0.003 & 0.05 \\
\hline Other & $2.46^{\mathrm{b}}$ & $2.50^{\mathrm{ab}}$ & $2.61^{\mathrm{a}}$ & 0.05 & 0.03 \\
\hline \multicolumn{6}{|l|}{ Summation } \\
\hline$<\mathrm{C} 16$ & $23.10^{\mathrm{a}}$ & $19.37^{\mathrm{b}}$ & $17.94^{\mathrm{c}}$ & 0.28 & $<0.001$ \\
\hline $\mathrm{C} 16$ and $\mathrm{C} 16: 1$ & $26.41^{\mathrm{a}}$ & $23.79^{\mathrm{b}}$ & $23.80^{\mathrm{b}}$ & 1.88 & $<0.001$ \\
\hline$>\mathrm{C} 16$ & $50.50^{\mathrm{c}}$ & $56.85^{\mathrm{b}}$ & $58.26^{\mathrm{a}}$ & 1.94 & $<0.001$ \\
\hline \multicolumn{6}{|l|}{ Desaturase index } \\
\hline $14: 1 /(14: 0+14: 1)$ & 0.070 & 0.069 & 0.072 & 0.008 & 0.78 \\
\hline $16: 1 /(16: 0+16: 1)$ & 0.040 & 0.040 & 0.043 & 0.003 & 0.30 \\
\hline $18: 1 /(18: 0+18: 1)$ & 0.639 & 0.644 & 0.645 & 0.009 & 0.87 \\
\hline$c 9, t 11 \mathrm{CLA} /(18: 1 t 11+c 9, t 11 \mathrm{CLA})$ & $0.248^{\mathrm{b}}$ & $0.288^{\mathrm{a}}$ & $0.273^{\mathrm{a}}$ & 0.008 & $<0.001$ \\
\hline
\end{tabular}

${ }^{\mathrm{a}, \mathrm{b}}$ Means within a row with different superscripts differ $(P<0.05)$.

${ }^{1}$ Supplements were amide-protected CLA (AP-CLA) and lipid-encapsulated CLA (LE-CLA).

${ }^{2}$ Values represent an average of d 6 and 7 of supplementation.

${ }^{3}$ Statistical probability of treatment effects.

(Chouinard et al., 1999a, 1999b; Baumgard et al., 2000; 2001; Loor and Herbein, 2003; Mackle et al., 2003). In contrast, studies conducted with pasture-fed animals have reported significant increases in protein yield as well as milk yield when CLA was supplemented (Medeiros et al., 2000; Gulati et al., 2001); these are situations in which the energy content of the diet is limiting and protein is present in excess. Reducing energy demands through decreased milk fat synthesis in these situations may allow for a repartitioning of energy for the production of milk and milk protein. Similarly, CLA supplementation caused an increased milk yield in early lactation cows, but this was not accompanied by an increased protein yield consistent with the fact that the supply of amino acids would be limited in early lactation (Bernal-Santos et al., 2003). We utilized mid- lactation cows that were fed a dry diet in our metabolic unit, and performance was lower then when cows were housed at the University farm and fed a traditional TMR. Thus, in the present study an apparent repartitioning of energy also occurred when cows received the CLA supplements as indicated by the significant increase in milk protein yield $(+7 \%)$ and the small nonsignificant increase in milk yield $(+5 \%)$.

The efficacy of a rumen-protected trans-10, cis-12 CLA supplement is reflected by the extent to which it causes milk fat depression. The proportional transfer of trans-10, cis-12 CLA from the abomasum into milk fat has been shown to be relatively constant (de Veth et al., 2004) and increasing the trans-10, cis-12 CLA content of milk corresponds to a curvilinear reduction in milk fat synthesis (Peterson et al., 2002). The transfer of 
Table 5. Comparison of rumen-protected supplements of conjugated linoleic acid (CLA).,1,3,4

\begin{tabular}{llllll}
\hline $\begin{array}{l}\text { Rumen protection } \\
\text { method }\end{array}$ & $\begin{array}{l}\text { 10,12 CLA in } \\
\text { MF, g/d }\end{array}$ & $\begin{array}{l}\text { Transfer to } \\
\text { MF, \% }\end{array}$ & $\begin{array}{l}\text { Reduction } \\
\text { in MFY, } \%\end{array}$ & $\begin{array}{l}\text { Reduction in } \\
\text { MFY, }{ }^{5} \text { g/d }\end{array}$ & Study \\
\hline Lipid-encapsulated & 0.79 & 7.9 & 22 & 280 & Present \\
Amide & 0.71 & 7.1 & 21 & 268 & Present \\
Formaldehyde & 0.70 & 7.0 & 44 & 347 & de Veth et al., 2003 \\
Calcium salts & 0.32 & 3.2 & 34 & 271 & de Veth et al., 2003 \\
\hline
\end{tabular}

${ }^{1}$ The CLA used in all 4 supplements originated from the same batch. Calcium salts and amide-protection methods utilized the free fatty acid form of CLA, while the formaldehyde and lipid encapsulated products were manufactured from the methyl ester form of CLA.

${ }^{2}$ Supplements provided $10 \mathrm{~g} / \mathrm{d}$ of trans-10, cis-12 CLA. Milk yields for animals receiving supplements averaged $42.7 \mathrm{~kg} / \mathrm{d}$ for the present study, and $20.1 \mathrm{~kg} / \mathrm{d}$ for de Veth et al., 2003.

${ }^{3} \mathrm{MF}=$ Milk fat; MFY = milk fat yield.

${ }^{4}$ Transfer to MF calculated as: [(g of $t$-10, $c$-12 CLA in MF per day $\div \mathrm{g}$ of $t$-10, $c$-12 CLA fed per day)(100)].

${ }^{5}$ Decreases in MFY caused by the amide and lipid-encapsulated products were statistically similar. In the separate study conducted by de Veth et al. (2003), the decreases in MFY caused by the formaldehyde and calcium salt products were statistically similar.

trans-10, cis-12 CLA from a rumen-protected supplement into milk fat is influenced by the ability of the supplement to provide protection from rumen metabolism as well as postruminal availability (Wu and Papas, 1997). Therefore, incorporation of trans-10, cis-12 CLA into milk fat is a good method for evaluating rumenprotected CLA products because protection from rumen metabolism as well as postruminal availability are assessed.

A unique feature of the present study is that it provided an identical daily dose of trans-10, cis-12 CLA originating from the same batch of CLA as was used in a separate study by de Veth et al. (2003) that compared calcium salt and formaldehyde-protected products. The reduction in milk fat yield, as well as the transfer efficiency of trans-10, cis-12 CLA into milk fat for each of the 4 rumen-protected supplements are presented in Table 5. The 2 studies were completed independently, so statistical comparison is not possible. However, it is interesting to note that all supplements caused similar degrees of reduction in milk fat secretion (Table 5). In general, the transfer efficiencies of trans-10, cis-12 CLA from rumen-protected supplements are much lower than the $\sim 20 \%$ transfer efficiencies reported for abomasal infusion studies (Chouinard et al., 1999a, 1999b; Baumgard et al., 2000, 2001; Peterson et al., 2002). Thus, a large proportion of the CLA in the rumen-protected supplements must be metabolized in the rumen or unavailable for postruminal absorption. Transfer of trans-10, cis-12 CLA from the formaldehyde-protected CLA supplement was similar (7.0\%) to the transfer observed for the 2 rumen-protected supplements used in the present study (Table 5). In contrast, the calcium salts of CLA had a transfer efficiency of only $3.2 \%$, which is similar to the transfer efficiencies reported for longer-term studies using calcium salts of CLA (Perfield et al., 2002; Bernal-Santos et al., 2003). In these situa- tions the milk fat content of trans-10, cis-12 CLA does not effectively explain the observed milk fat depression when plotted on the curve developed by Peterson et al. (2002). It has been hypothesized that the reason for this is that other unique fatty acids are formed in the rumen, which are also potent inhibitors of milk fat synthesis (Bauman and Griinari, 2003; Bauman et al., 2003). This could provide an explanation for why the calcium salt supplements of CLA have about one-half the transfer efficiency of trans-10, cis-12 CLA found for other rumen-protected products, yet the reduction in milk fat synthesis is similar (Table 5). Of course, the most dependable CLA supplement would transfer a specific quantity of trans-10, cis-12 CLA into milk fat per amount fed without variations introduced by particular rumen conditions or rumen fermentation.

Overall, supplementation of an AP-CLA or a LE-CLA product resulted in similar reductions in milk fat with no effect on feed intake or milk yield. Reduction in milk fat yield had achieved nadir by the sixth day of supplementation, and transfer of trans-10, cis-12 CLA into milk fat was similar for both rumen-protected CLA products. The AP-CLA and LE-CLA supplements were able to reduce milk fat in a controlled manner with no adverse effects. As this was a short-term study with very limited animal numbers, further research with these supplements will be needed to verify and extend results.

\section{ACKNOWLEDGMENTS}

Authors gratefully acknowledge the contributions of J. Mikko Griinari (Clanet Ltd, Espoo, Finland) in the development of this investigation and evaluation of the results. The authors also thank P. Lee and D. Putnam (Balchem Encapsulates) for the preparation of the lipidencapsulated supplement and T. Jenkins (Clemson 
University, Clemson, SC) for consultation and assistance in obtaining the amide-protected supplement. The support of the following students and colleagues at Cornell University in implementing the study is also gratefully acknowledged and appreciated: S. Bean, J. McFadden, D. Dwyer, B. English, L. Furman, G. Birdsall, B. Jones, and D. Ceurter.

\section{REFERENCES}

Association of Official Analytical Chemists, International. 2000. Official Methods of Analysis. 17th Ed. AOAC, Arlington, VA.

Bauman, D. E., B. A. Corl, L. H. Baumgard, and J. M. Griinari. 2001. Conjugated linoleic acid (CLA) and the dairy cow. Pages 221-250 in Recent Advances in Animal Nutrition 2001. P. C. Garnsworthy, and J. Wiseman, eds. Nottingham University Press, Nottingham, UK.

Bauman, D. E., and J. M. Griinari. 2003. Nutritional regulation of milk fat synthesis. Annu. Rev. Nutr. 23:203-227.

Bauman, D. E., B. A. Corl, and D. G. Peterson. 2003. The biology of conjugated linoleic acids in ruminants. Pages 146-173 in Advances in Conjugated Linoleic Acid Research, Vol. 2. J.-L. Sébédio, W. W. Christie, and R. Adlof, eds. AOCS Press, Champaign, IL.

Baumgard, L. H., B. A. Corl, D. A. Dwyer, A. Sæbø, and D. E. Bauman. 2000. Identification of the conjugated linoleic acid isomer that inhibits milk fat synthesis. Am. J. Physiol. 278:R179-R184.

Baumgard, L. H., J. K. Sangster, and D. E. Bauman. 2001. Milk fat synthesis in dairy cows is progressively reduced by increasing supplemental amounts of trans-10, cis-12 conjugated linoleic acid (CLA). J. Nutr. 131:1764-1769.

Baumgard, L. H., B. A. Corl, D. A. Dwyer, and D. E. Bauman. 2002. Effects of conjugated linoleic acids (CLA) on tissue response to homeostatic signals and plasma variables associated with lipid metabolism in lactating dairy cows. J. Anim. Sci. 80:1285-1293.

Bernal-Santos, G., J. W. Perfield II, T. R. Overton, and D. E. Bauman. 2003. Production responses of dairy cows to dietary supplementation with conjugated linoleic acid (CLA) during the transition period and early lactation. J. Dairy Sci. 86:3218-3228.

Chouinard, P. Y., L. Corneau, D. M. Barbano, L. E. Metzger, and D. E. Bauman. 1999a. Conjugated linoleic acids alter milk fatty acid composition and inhibit milk fat secretion in dairy cows. J. Nutr. 129:1579-1584.

Chouinard, P. Y., L. Corneau, A. Sæbø, and D. E. Bauman. 1999b. Milk yield and composition during abomasal infusion of conjugated linoleic acids in dairy cows. J. Dairy Sci. 82:2737-2745.

Christie, W. W. 1982. A simple procedure for rapid transmethylation of glycerolipids and cholesteryl esters. J. Lipid Res. 23:1072-1075.

Christie, W. W. 1989. Gas Chromatography and Lipids: A Practical Guide. The Oily Press, Ayr, Scotland.

de Veth, M. J., J. M. Griinari, A. M. Pfeiffer, and D. E. Bauman. 2004. Effect of CLA on milk fat synthesis in dairy cows: Comparison of inhibition by methyl esters and free fatty acids, and relationships among studies. Lipids 39:365-372.

de Veth, M. J., J. W. McFadden, J. M. Griinari, S. K. Gulati, N. D. Luchini, and D. E. Bauman. 2003. Comparison of the effect of different rumen protected forms of CLA on milk fat synthesis. J. Dairy Sci. 86(Suppl. 1):146-147. (Abstr.).

Fox, D. G., C. J. Sniffen, J. D. O’Connor, J. B. Russell, and P. J. Van Soest. 1992. A net carbohydrate and protein system for evaluating cattle diets: III. Cattle requirements and diet adequacy. J. Anim. Sci. 70:3578-3596.

Giesy, J. G, M. A. McGuire, B. Shafii, and T. W. Hanson. 2002. Effect of dose of calcium salts of conjugated linoleic acid (CLA) on percentage and fatty acid content of milk fat in midlactation Holstein cows. J. Dairy Sci. 85:2023-2029.

Gulati, S. K., S. M. Kitessa, J. R. Ashes, E. Fleck, E. B. Byers, Y. G. Byers, and T. W. Scott. 2000. Protection of conjugated linoleic acids from ruminal hydrogenation and their incorporation into milk fat. Anim. Feed Sci. Technol. 86:139-148.

Gulati, S. K., S. McGrath, P. C. Wynn, and T. W. Scott. 2001. Rumen protected conjugated linoleic acids: Effects on milk composition in dairy cows. Proc. Nutr. Soc. Aust. 25:S85 (Abstr.).

Hara, A., and N. S. Radin. 1978. Lipid extraction of tissues with a low-toxicity solvent. Anal. Biochem. 90:420-426.

Jenkins, T. C. 1995. Butylsoyamide protects soybean oil from ruminal biohydrogenation: Effects of butylsoyamide on plasma fatty acids and nutrient digestion in sheep J. Anim. Sci. 73:818-823.

Jenkins, T. C. 1998. Lactation performance and fatty acid composition of milk from Holstein cows fed 0 to $5 \%$ oleamide. J. Dairy Sci. 82:1525-1531.

Loor, J. J., and J. H. Herbein. 1998. Exogenous conjugated linoleic acid isomers reduce bovine milk fat concentration and yield by inhibiting de novo fatty acid synthesis. J. Nutr. 128:2411-2419.

Loor, J. J., and J. H. Herbein. 2003. Reduced fatty acid synthesis and desaturation due to exogenous trans 10,cis 12-CLA in cows fed oleic or linoleic oil. J. Dairy Sci. 86:1354-1369.

Mackle, T. R., J. K. Kay, M. J. Auldist, A. K. H. McGibbon, B. A. Philpott, L. H. Baumgard, and D. E. Bauman. 2003. Effects of abomasal infusion of conjugated linoleic acid on milk fat concentration and yield from pasture-fed dairy cows. J. Dairy Sci. 86:644-652

Medeiros, S. R., D. E. Oliveira, L. J. M. Aroeira, M. A. McGuire, D. E. Bauman, and D. P. D. Lanna. 2000. The effect of long term supplementation of conjugated linoleic acid (CLA) to dairy cows grazing tropical pasture. J. Dairy Sci. 83(Suppl. 1):169. (Abstr.).

National Research Council. 2001. Nutrient Requirements of Dairy Cattle, 7th rev. ed. National Academy of Sciences, Washington, DC.

Perfield, J. W., II, G. Bernal-Santos, T. R. Overton, and D. E. Bauman. 2002. Effects of dietary supplementation of rumen-protected conjugated linoleic acid (CLA) in dairy cows during established lactation. J. Dairy Sci. 85:2609-2617.

Perfield, J. W., II, A. Sæbø, and D. E. Bauman. 2004. Use of conjugated linoleic acid (CIA) enrichments to examine the effects of trans8, cis-10 CLA and cis-11, trans-13 CLA on milk fat synthesis. J. Dairy Sci. 87:1196-1202.

Peterson, D. G., L. H. Baumgard, and D. E. Bauman. 2002. Short communication: Milk fat response to low doses of trans-10, cis12 conjugated linoleic acid (CLA). J. Dairy Sci. 85:1764-1766.

Putnam, D., J. Garrett, and L. Kung. 2003. Evaluation key to use of rumen-stable encapsulates. Feedstuffs 75[15]:10-12.

Sæbø, A. 2003. Commercial synthesis of conjugated linoleate. Pages 71-81 in Advances in Conjugated Linoleic Acid Research, Vol. 2. J.-L. Sébédio, W. W. Christie, and R. Adlof, eds. AOCS Press, Champaign, IL.

SAS. 2001. SAS/STAT Users Guide (Release 8.0). SAS Inst., Inc., Cary, NC.

Viswanadha, S., J. G. Giesy, T. W. Hanson, and M. A. McGuire. 2003. Dose response of milk fat to intravenous administration of the trans-10, cis-12 isomer of conjugated linoleic acid. J. Dairy Sci. 86:3229-3236.

Wu, Z., and A. Papas. 1997. Rumen-stable delivery systems. Adv. Drug Deliv. Rev. 28:323-334. 